\title{
Development of A Rapid Method for the Diagnosis of Citrus Greening Disease using the Polymerase Chain Reaction
}

\author{
T. H. HunG, M. L. Wu and H. J. Su \\ Authors' address: Department of Plant Pathology, National Taiwan University, Taipei 106, Taiwan (correspondence to \\ T. H. Hung) \\ With 5 figures
}

Received January 5, 1999; accepted March 29, 1999

Keywords: citrus greening, greening fastidious bacterium, polymerase chain reaction (PCR)

\begin{abstract}
The fastidious bacterium causing citrus greening disease occurs in uneven and low concentrations in the sieve tubes of host plants. A rapid and sensitive assay based on the polymerase chain reaction (PCR) has been developed using the primers derived from the sequences of the cloned DNA fragment of greening fastidious bacterium (GFB) to detect GFB infection in citrus. One set of the primer pairs (named 226-primer pair), which generates a 226 bp GFB-specific fragment from total DNA templates purified from diseased citrus plants, was tested and chosen for PCR amplification. The PCR-based assay using this 226-primer pair effectively detected GFB infection in various citrus cultivars collected from different Asian countries. This detection technique, which can be completed within $6 \mathrm{~h}$, offers a rapid and efficient method for accurate diagnosis of citrus greening disease.
\end{abstract}

\section{Zusammenfassung}

Entwicklung einer schnellen Diagnosemethode für Citrus Greening Disease mit Hilfe der Polymerasekettenreaktion

Das anspruchsvolle Bakterium, welches die citrus greening Krankheit verursacht, kommt in ungleichmäßigen und niedrigen Konzentrationen in den Leitbündeln der Wirtspflanzen vor. Entwickelt wurde eine schnelle und empfindliche Analysemethode basierend auf der Polymerasekettenreaktion (PCR), um Infektionen durch das Bakterium in Citruspflanzen nachweisen zu können. Die eingesetzten Primer wurden aus Sequenzen der geklonten DNA-Fragmente des greening fastidious Bakterium (GFB) hergestellt. Ein Satz der Primerpaare, 226-Primerpaar genannt wurde getestet und für die PCRAmplifikation ausgewählt. Aus erkrankten Citruspflanzen wurden DNA-Templates gewonnen und gereinigt. Das 226-Primerpaar erzeugte von diesen Templates ein 226 bp, GFB spezfisches Fragment. Mit Hilfe dieser 226-Primerpaar basierenden PCR-Analysemethode konnten GFB-Infektionen in unterschiedlichen Citrussorten von verschiedenen asiatischen Ländern nachgewiesen werden. Dieser Nachweisassay, der innerhalb von 6 Stunden durchgeführt werden kann, bietet eine schnelle und zuversichtliche Methode für eine genaue Bestimmung der citrus greening disease.

\section{Introduction}

Citrus greening is a very severe disease of citrus, especially in Asia. It is caused by a nonculturable fastidious bacterium that occurs in the sieve tubes of its hosts (Garnier et al., 1984). The pathogen infects citrus trees of almost all cultivars, and causes substantial economic loss to the citrus industry by shortening the lifespan of infected trees. The greening fastidious bacterium (GFB) has been difficult to detect hithertobecause of its low concentration and uneven distribution in its natural hosts ( $\mathrm{Su}$ and Chang, 1974). The disease therefore can not be diagnosed easily by conventional procedures, such as electron microscopic examination of ultra-thin sections, bioassay on indicator plants, and enzyme-linked immunosorbent assay (ELISA) with polyclonal or monoclonal antibodies.

In 1991, biotinylated nonradioactive DNA probes were developed for the specific and sensitive detection of GFB infection in citrus (Su et al., 1991). The DNA probes were prepared by cloning GFB-DNA purified from infected citrus. One clone containing a $0.24 \mathrm{~kb}$ GFBspecific fragment was selected for the development of a DNA probe. Dot hybridization tests with this nonradioactive probe offered a better method to detect GFB (Hung et al., 1999). This probe has been used widely in the quarantine and ecological survey for citrus greening disease in Taiwan.

Citrus greening has a long incubation period, and many symptomless but infected citrus plants occur in fields. Although DNA hybridization using a biotinylated 
DNA probe is a more sensitive diagnostic tool than conventional methods, latently infected plant samples only generate a relatively weak signal in dot hybridization tests.

For more effective and accurate detection of GFB, a more sensitive assay based on the polymerase chain reaction (PCR) using a pair of primers chosen from the sequences of the cloned GFB-specific DNA fragment $(0.24 \mathrm{~kb})$ has recently been developed by the authors. The PCR-based assay is more sensitive and quicker, particularly when the concentration of GFB in infected hosts is very limited. According to preliminary tests, the total DNA extracted from a citrus host could be used in the PCR-based assay without conspicuous interference and that GFB could be detected within $6 \mathrm{~h}$ even using as little as $0.25 \mathrm{~g}$ of citrus leaf midrib. Therefore, the PCR technique and minipreparation of total DNA were combined to design a simple and rapid protocol for GFB detection. The protocol is now the standard method for the routine detection of GFB, and is used to assist the quarantine and management of the pathogen-free nursery system in Taiwan. This rapid method for GFB detection and its application in detection of geographically different GFB strains collected from Taiwan and the other countries is describe herein.

\section{Materials and Methods Plants}

GFB-infected Tankan tangor (Citrus tankan Hay.) trees with characteristic symptoms of citrus greening were collected from northern Taiwan and used for GFB DNA cloning. The other GFB-infected citrus samples were from fields in Okinawa (Japan), Kuangtung (China), Hanoi (Vietnam), Davao (Philippines), Sarawak (Malaysia), Chiang Mai (Thailand), Delhi (India), Al Mofaja (Saudi Arabia), Pretoria (South Africa) and Taiwan. These samples were obtained from 'The International Cooperative Project on the Establishment of Virus-free Nursery System of Tropical Fruit Trees in the Asia and Pacific Area' which is supported by Food \& Fertilizer Technology Center for the Asian and Pacific Region. All GFB-infected plants were kept in a greenhouse. Healthy negative control citrus plants were obtained from pathogen-free seedlings by the shoot-tip grafting technique (Murashige et al., 1972; Su and Chu, 1984) and grown in the healthy plant greenhouse.

\section{Cloning of GFB-specific DNA fragments from infected citrus plants}

For isolation of GFB, $50 \mathrm{~g}$ of infected leaf midribs were ground to a powder in liquid nitrogen and resuspended in $150 \mathrm{ml}$ GFB extraction buffer [ $300 \mathrm{~mm}$ mannitol, $50 \mathrm{~mm}$ Tris- $\mathrm{HCl}(\mathrm{pH} 7.4), 5 \mathrm{~mm}$ EDTA, $4 \mathrm{~mm} \beta$-mercaptoethanol]. This suspension was centrifuged three times at low speed $(4000 \times \boldsymbol{g}$ for $15 \mathrm{~min})$ to remove most of host debris. Crude GFB pellets were collected by high-speed centrifugation $(12000 \times \boldsymbol{g}$ for $30 \mathrm{~min})$. To reduce contamination, the crude GFB fraction was centrifuged in a continuous density gradient of sucrose $(0.6-1.6 \mathrm{M})$. The two bands below the meniscus were collected, diluted with five volumes of GFB extraction buffer, and centrifuged at $12000 \times \boldsymbol{g}$ for $30 \mathrm{~min}$. The pellets were resuspended in DNA extraction buffer for preparation of GFB-DNA.

GFB-DNA was prepared as described later. After preparation of GFB-DNA, the DNA extracts were dissolved in TE buffer [10 mM Tris-HCl $(\mathrm{pH} 8.0), 1 \mathrm{~mm}$ EDTA] containing DNase-free RNase $(20 \mu \mathrm{g} / \mathrm{ml})$. For DNA cloning, the DNA sample was digested with EcoRI restriction enzyme, then ligated with EcoRI linealized pBS plasmid (Stratagene Biotec, La Jolla, CA, USA). Recombinant plasmids were used to transform competent Escherichia coli JM 83 by the method described by Sambrook et al. (1989). Ampicillin-resistant colonies were selected and screened by dot hybridization with biotin-labelled DNA preparations from GFB-infected Tankan tangor plants as well as from healthy Tankan tangor plants. The biotin-labelled DNA was prepared by nick translation (Gibco BRL, Gaithersburg, MD, USA) with biotinylated dATP. A minipreparation of each colony was made to isolate recombinant plasmids by alkaline lysis methods. Plasmid DNA ( $3 \mu \mathrm{l})$ from each individual colony, after suspension in $6 \times$ SSC buffer $[0.9 \mathrm{M} \mathrm{NaCl}, 0.09 \mathrm{M}$ sodium citrate, $(\mathrm{pH} 7.0)]$, was spotted on Nylon membrane. The membrane was baked, prehybridized, hybridized and assayed according to the manufacturer's instruction of BlueGENE detection system (Gibco BRL).

The recombinant clones which hybridized with biotinlabelled DNA from diseased but not healthy Tankan plants were selected and used as the candidate clones for developing GFB-DNA probes. The DNA from each candidate clone was labelled with biotinylated dATP. The specificity and sensitivity of biotinylated probes were verified repeatedly by hybridization tests with DNAs isolated from either diseased or healthy citrus plants.

\section{Sequencing}

Qiaprep Spin Miniprep Kit (Qiagen, Hilden, Germany) was used for preparing the minipreparation of recombinant plasmid. DNA sequencing was carried out by using an ABI PRISM ${ }^{\circledR}$ Dye Terminator Cycle Sequencing Ready Reaction Kit (Perkin Elmer, Norwalk, CT, USA) and analysed in an ABI PRISM 310 Genetic Analyzer as recommended by the manufacturer. The universal primers used for sequencing were $\mathrm{T} 3$ and $\mathrm{T} 7$.

\section{Primers}

Two opposing primers for the PCR-based detection of GFB were chosen from the sequence of cloned GFBspecific DNA fragments. The primer pair, composed of the forward primer 5'-CAC CGA AGA TAT GGA CAA CA-3' and the reverse primer 5'-GAG GTT CTT GTG GTT TTT CTG-3', were designed to amplify a GFBspecific DNA fragment by PCR.

\section{PCR conditions}

PCR was performed using $25 \mu \mathrm{l}$ of reaction mixture containing $20 \mathrm{~mm}$ Tris- $\mathrm{HCl}(\mathrm{pH} 8.4), 50 \mathrm{~mm} \mathrm{KCl}, 4 \mathrm{~mm}$ $\mathrm{MgCl}_{2}, 0.2 \mathrm{~mm}$ each dATP, dTTP, dCTP and dGTP, 
50 ng Forward primer, 50 ng Reverse primer, 0.75 units of Taq DNA polymerase (Gibco BRL) and $200 \mathrm{ng}$ template of the nucleic acid preparation. The thermal cycle conditions were: one cycle at $94^{\circ} \mathrm{C}$ for $3 \mathrm{~min} ; 30$ cycles at $94^{\circ} \mathrm{C}$ for $1 \mathrm{~min}, 56^{\circ} \mathrm{C}$ for $1 \mathrm{~min}$, and $72^{\circ} \mathrm{C}$ for $2 \mathrm{~min}$; then followed by a $72^{\circ} \mathrm{C}$ extension for $10 \mathrm{~min}$. Reactions were carried out in a DNA Thermal Cycler 480.

\section{Nucleic acid preparations}

For rapid and mass-screening, minipreparations of total nucleic acid extracts of field samples were used as templates for PCR. Nucleic acid samples were prepared using a method with minor modification as described by Lee and Davis (1988), Lee et al. (1988, 1990). Leaf midrib $(\approx 250 \mathrm{mg})$ was powdered in liquid nitrogen, and each sample was suspended in $1.5 \mathrm{ml}$ of DNA extraction buffer [1 м Tris- $\mathrm{HCl}$ (pH 8.0), 0.5 м EDTA, $5 \mathrm{~m} \mathrm{NaCl,} \mathrm{1 \%} \mathrm{N-}$ Lauroylsarcosine], and transferred to a $1.5 \mathrm{ml}$ Eppendorf tube. After incubation at $55^{\circ} \mathrm{C}$ for $1 \mathrm{~h}$, the sample was centrifuged at $4000 \times \boldsymbol{g}$ for $5 \mathrm{~min}$. The supernatanat (*800 $\mu \mathrm{l}$ ) was collected, and $100 \mu \mathrm{l} 5 \mathrm{M} \mathrm{NaCl}$ and $100 \mu \mathrm{l}$ $10 \%$ CTAB (hexadecyl-trimethyl-ammonium-bromide) in $0.7 \mathrm{M} \mathrm{NaCl}$ were added, and the mixture incubated at $65^{\circ} \mathrm{C}$ for $10 \mathrm{~min}$. The sample was subjected to one cycle of chloroform/isoamyl alcohol (24:1) extraction, and the aqueous supernatant was then re-extracted by an additional cycle of phenol/chloroform/isoamyl alcohol $(25: 24: 1)$. The nucleic acids were precipitated by mixing $600 \mu \mathrm{l}$ of the supernatant and $360 \mu \mathrm{l}$ isopropanol followed by centrifugation at $12000 \times g$ for $10 \mathrm{~min}$. The pellets were washed with $70 \%$ ethanol, dried, and resuspended in $150 \mu \mathrm{l}$ TE buffer.

\section{Analysis of PCR products by electrophoresis}

The PCR products were identified by gel electrophoresis using $1.4 \%$ agarose (Boehringer Mannheim, Mannheim, Germany) in TAE buffer [ $40 \mathrm{~mm}$ Tris-acetate ( $\mathrm{pH} 8.0$ ), $1 \mathrm{~mm}$ EDTA]. After electrophoresis, the gel was stained with ethidium bromide $(0.5 \mu \mathrm{g} / \mathrm{ml})$ and photographed.
The 100 bp DNA Ladder set (Promega, Madison, WI USA) was included as size markers. The electrophoresis was run for 30 to $40 \mathrm{~min}$ using a high voltage $(100 \mathrm{~V})$.

\section{Southern hybridizations}

After electrophoresis, the gel containing the PCR product was incubated in $0.2 \mathrm{~N} \mathrm{HCl}$ for $10 \mathrm{~min}$, denatured in 0.5 $\mathrm{N} \mathrm{NaOH}$ and $1.5 \mathrm{M} \mathrm{NaCl}$ for $35 \mathrm{~min}$, and equilibrated in transfer buffer ( $\left.1 \mathrm{M} \mathrm{NH}_{4} \mathrm{Oac}, 0.02 \mathrm{~N} \mathrm{NaOH}\right)$ for $10 \mathrm{~min}$. The PCR products were transferred from the agarose gel to a Nylon membrane (Nytran. Schleicher \& Schuell, Dassel, Germany) overnight. The plasmid containing the GFB-specific DNA fragment which corresponded to the PCR product was used as the hybridization probe. The plasmid was digested with restriction enzyme EcoRI and labelled with biotinylated dATP by nick translation (Gibco BRL) according to the manufacturer's instruction. For DNA markers, biotin-labelled $100 \mathrm{bp}$ DNA Ladders prepared by nick translation were included in the hybridization mixture. Hybridizations were performed at $68^{\circ} \mathrm{C}$, and the bound probes were detected with BluGENE detection system (Gibco BRL) according to the manufacturer's instructions.

\section{Results \\ Cloning and sequencing of GFB-specific DNA fragments}

A total of 836 transformant $E$. coli colonies were obtained from the preliminary GFB-DNA cloning process. All such colonies were then screened individually by dot hybridization with biotin-labelled DNA preparations from both GFB-infected and healthy plants. Only three clones were GFB-specific (Hung et al., 1999). The recombinant plasmids were extracted individually from these three GFB-specific colonies and biotinylated to develop probes. One clone containing a GFB-specific fragments (named GSF1) was selected for DNA sequencing. The sequence of the 243 nucleotides of GSF1 is shown in Fig. 1.

\section{$\stackrel{5^{\prime}}{\stackrel{3}{\prime}}$ \\ GAATTCDACC GAAGATATGG ACAACATAAT TATTACAACA ATAACCGAAA CTTAAGGTGG CTTCTATACC TGTTGTATTA ATAATGTTGT TATTGGCTTT}

\section{CCAAAACCTC ACTCCGAGAC GGCCAGAATA TCTTCTTAGA CTCATCCCTA GGTTTTGGAG TGAGGCTCTG CCGGTCTTAT AGAAGAATCT GAGTAGGGAT}

\section{ACTTGCTTAA AAAATTTAAC ACAGCCAACC TATTATCTCC CATCAAAGGA TGAACGAATT TTTTAAATTG TGTCGGTTGG ATAATAGAGG GTAGTTTCCT}

\section{GAAACTCTCC AATCTTAGAA CACGCCTTGA TGTATAAAGC AAGAAAAAAA}

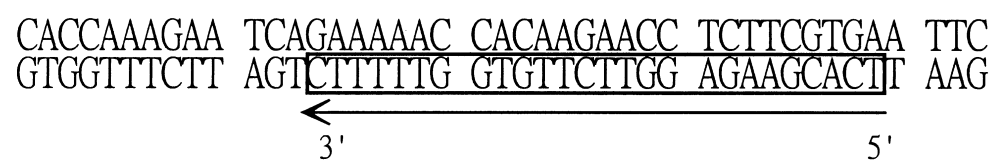

Fig. 1 The sequence of 243 nucleotides of GFB-specific fragment 1 (GSF1). The EcoR I restriction sites for cloning are located at two ends. The sequences of two opposing primers (226-primer pair) chosen for PCR amplification are framed 


\section{$\begin{array}{lllllllllll}M & 1 & 2 & 3 & 4 & 5 & 6 & 7 & 8 & 9 & 10\end{array}$}

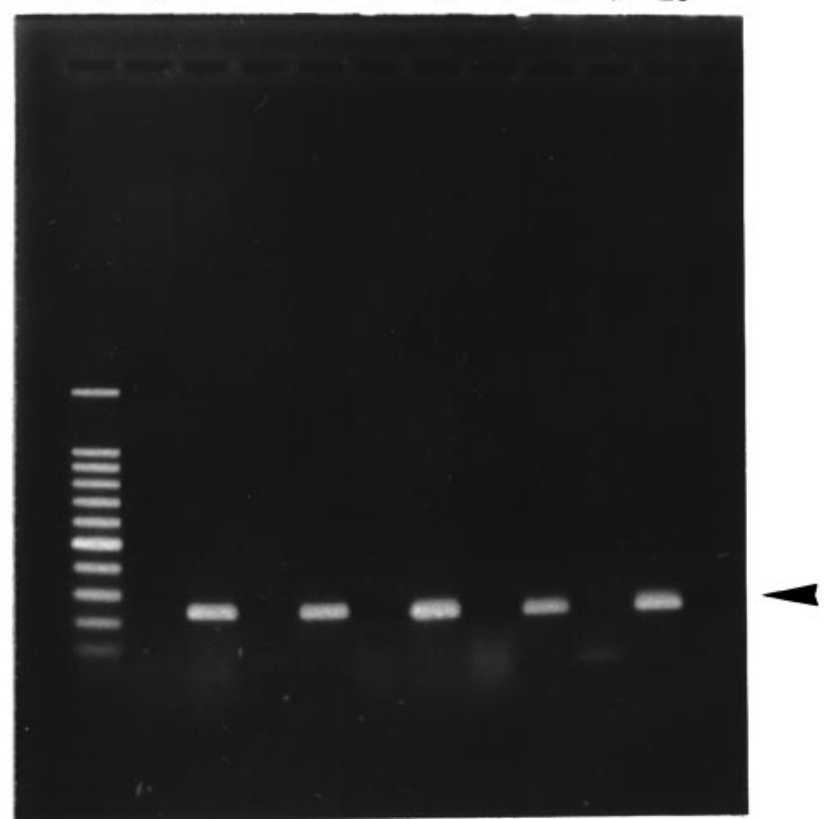

Fig. 2 Detection of greening fastidious bacterium (GFB) in severa infected citrus cultivars by the polymerase chain reaction (PCR) using the 226-primer pair. The PCR products were analysed by electrophoresis in a $1.4 \%$ agarose gel. The GFB-specific product of $226-\mathrm{bp}$ (arrowed) fragment was found in all diseased citrus samples including Ponkan mandarin (lane 2), Tankan tangor (lane 4), Luchen sweet orange (lane 6), Wentan pummelo (lane 8), and grapefruit (lane 10), but not in corresponding healthy samples including Ponkan (lane 1), Tankan (lane 3), Luchen (lane 5), Wentan (lane 7), and grapefruit (lane 9). The $100 \mathrm{bp}$ DNA ladders (lane M) were included as markers

\section{Oligonucleotide-primers for PCR amplification}

For PCR amplification, two opposing primers were chosen from two 5 '-ends of the GSF1 strands. The locations of the primers are also indicated in Fig. 1. The forward primer consists of 20 nucleotides, and the reverse primer 21. The primer pairs were expected to generated a 226 bp GFB-specific DNA fragment by PCR. The specific primer pair (named 226-primer pair) were used for GFB detections by PCR

\section{Detection of diseased citrus plants by PCR amplification with the 226-primer pair}

The total nucleic acid preparations from either diseased or healthy citrus plants collected in Taiwan were used as templates of PCR amplifications. The PCR products were analysed by electrophoresis in agarose gels (Fig. 2). All diseased samples from different citrus cultivars including Ponkan mandarin (Citrus poonensis Hort.), Tankan tangor ( $C$. tankan Hay.), Luchen sweet orange (Citrus sinensis Osb.), Wentan pummelo (Citrus grandis f. buntan Hay.), and grapefruit (Citrus paradisi Macf.) were positive for GFB DNA sequences by PCR using the 226primer pair. The PCR products migrated to the expected position by comparison with $100 \mathrm{bp}$ DNA ladders. The healthy samples were negative under the same PCR conditions.

\section{Southern hybridization}

To verify the specificity of amplified products, Southern hybridizations were performed using the biotin-labelled GSF1 DNA fragment as the probe. After agarose electrophoresis as described in Fig. 2, the PCR products on the agarose gel were transferred to a Nylon membrane, and hybridized with the biotin-labelled probe. An obvious and high degree of homology between the probes and the amplified products was observed (Fig. 3). This indicated that the PCR products amplified from the 226primer pair are related to GFB-specific DNA fragments originated from GFB-DNA.

\section{Detection of diseased citrus plants collected from different coun-} tries

The highly sensitive detection PCR method could be used also for citrus samples from different countries including Okinawa (Japan), Kuangtung (China), Hanoi (Vietnam), Davao (Philippines), Sarawak (Malaysia), Chiang Mai (Thailand), Delhi (India), and Al Mofaja (Saudi Arabia). All nucleic acid preparations of the various diseased plants collected from different Asian countries were found to be positive for GFB DNA sequences as detected by PCR using the 226-primer pair followed by agarose gel analysis (Fig. 4). However, one diseased sample from Pretoria (South Africa) was negative. All amplified DNA fragments from diseased samples collected from Asia have the same electromobility (226 bp) on agarose gel. All citrus cultivars used in this experiment (Fig. 4) are described in Table 1.

\section{Discussion}

The sensitive PCR assay is an excellent method for detecting GFB in its citrus hosts. Previously, it took at least 2 days to detect GFB infection by using dot hybridization

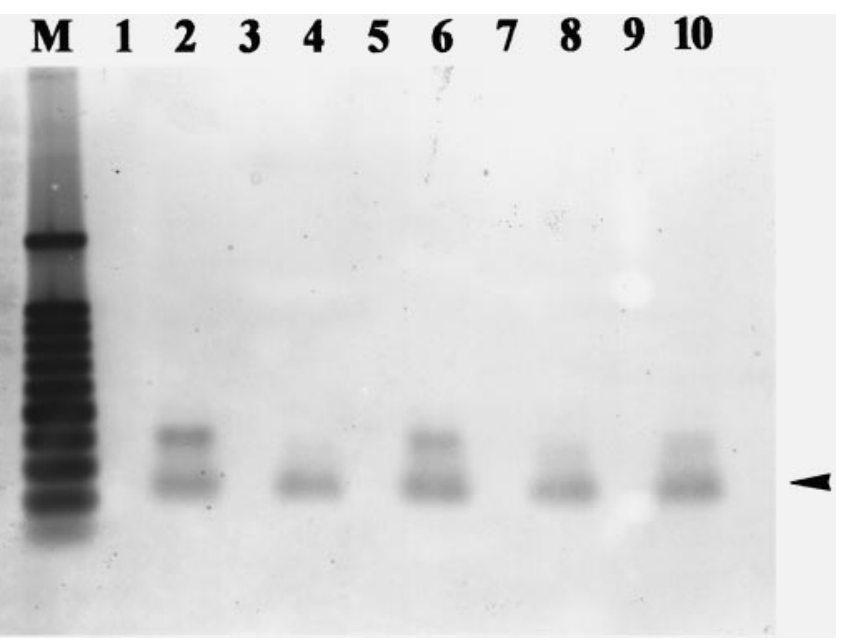

Fig. 3 Southern hybridization analysis of the PCR products amplified from nucleic acid preparation templates of diseased citrus plants. The biotinylated GSF1 DNA was used as a probe. The order of sample lanes is identical to that described in Fig. 2. The 226 bp products could hybridize with biotin-labelled GSF1 and result in strong signals at the expected position (arrowed). Another GFB-specific band appears at the 400 bp position (lane $2,6,10$ ) by comparison with 100 bp DNA ladders 


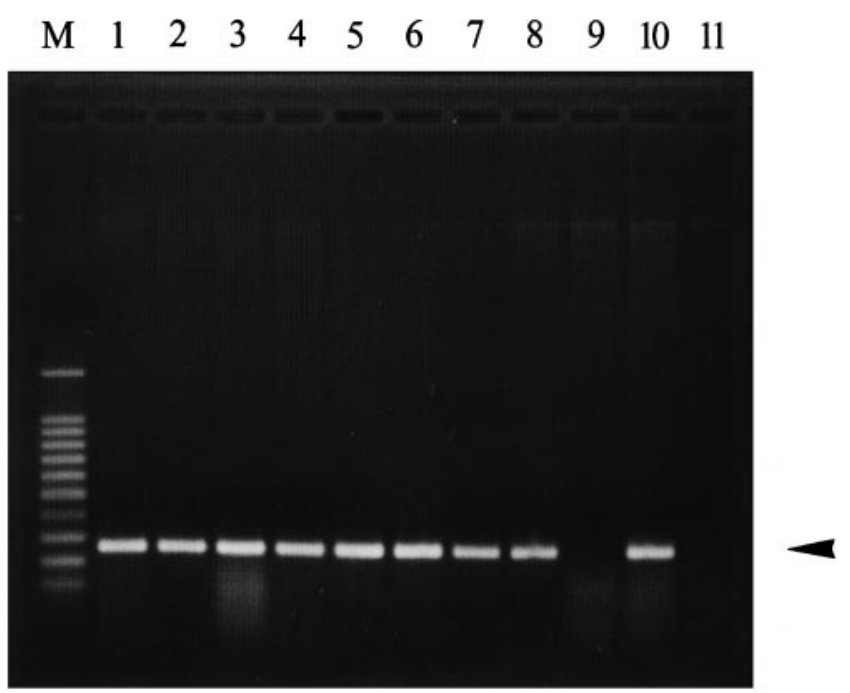

Fig. 4 The demonstration of geographically different GFB strains by PCR through the use of the 226-primer pair. The PCR products were analysed by electrophoresis in $1.4 \%$ agarose gel. The $226 \mathrm{bp}$ products (arrowed) were amplified from nucleic acid preparation templates of diseased citrus plants collected from different Asian countries, including Japan (lane 1), China (lane 2), Vietnam (lane 3), Philippines (lane 4), Malaysia (lane 5), Thailand (lane 6), India (lane 7), Saudi Arabia (lane 8) and Taiwan (lane 10). A negative result was obtained in PCR analysis using a nucleic acid preparation template of the diseased sample collected from South Africa (lane 9). Healthy citrus sample was used as a negative control (lane 11). The $100 \mathrm{bp}$ DNA ladders were used as size markers (lane $\mathrm{M}$ ). All citrus cultivars used in this experiment are described in Table 1

Table 1

The detection by PCR using the 226-primer pair of geographically different GFB-strains from various citrus cultivars collected from different countries. Data were summarized from Fig. 4

\begin{tabular}{|c|c|c|c|}
\hline $\begin{array}{c}\text { Lane } \\
\text { (on gel) }\end{array}$ & Citrus cultivar & Country & $\begin{array}{c}\text { Result } \\
\text { of detection } \\
\text { by PCR and } \\
\text { southern blotting }\end{array}$ \\
\hline 1 & Sikasya mandarin & Japan (Okinawa) & + \\
\hline 2 & $\begin{array}{l}\text { Hungchiang sweet } \\
\text { orange }\end{array}$ & China & + \\
\hline 3 & Valencia sweet orange & Vietnam & + \\
\hline 4 & Zinkom mandarin & Philippines & + \\
\hline 5 & Lankat mandarin & Malaysia & + \\
\hline 6 & $\begin{array}{l}\text { Som-Keo-Wanh } \\
\text { mandarin }\end{array}$ & Thailand & + \\
\hline 7 & Kino mandarin & India & + \\
\hline 8 & Willow leaf mandarin & Saudi Arabia & + \\
\hline 9 & Valencia sweet orange & South Africa & - \\
\hline 10 & Valencia sweet orange & Taiwan & + \\
\hline 11 & $\begin{array}{l}\text { Healthy Valancia } \\
\text { sweet orange (for } \\
\text { negative control) }\end{array}$ & Taiwan & - \\
\hline
\end{tabular}

a + , the sample showed positive for the GFB-specific DNA fragment amplified by PCR using 226-primer pair; -, the sample showed negative (no PCR product was found).

tests with biotinylated DNA probes, but combining the minipreparations of total nucleic acids from citrus hosts and PCR permitted much more rapid detection. The detailed procedures of this approach are summarized in
Step 1: Extraction of nucleic acids $(2 \mathrm{~h})$

$$
\begin{gathered}
\text { Citrus samples } \\
\downarrow \\
\text { Grinding } \\
\downarrow \\
55^{\circ} \mathrm{C} / 1 \mathrm{~h} \text { in DNA extraction buffer } \\
\downarrow \\
\frac{\text { CTAB treatment }}{65^{\circ} \mathrm{C} / 10 \text { min }} \\
\downarrow \\
\text { Extraction and Clarification } \\
\text { by chloroform /isoamyl alcohol }
\end{gathered}
$$

and phenol/chloroform/isoamyl alcohol extraction

$$
\downarrow
$$

Precipitation of nucleic acids

(dissolved in TE buffer)

Step 2: Thermal cycles $(3 \mathrm{~h})$

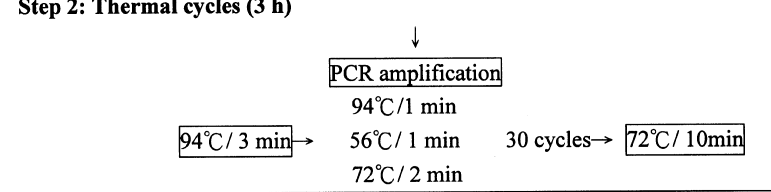

Step 3: Analysis of PCR products (1 h)

$$
\begin{aligned}
& \downarrow \\
& \text { Electrophoresis } \\
& 1.4 \% \text { agarose gel, } 100 \mathrm{v} / 30-40 \mathrm{~min} \\
& \downarrow \text { stained with } \mathrm{EtBr} \text { for } 5 \mathrm{~min} \\
& \text { Visualization } \\
& \text { under UV light }
\end{aligned}
$$

Fig. 5 Summary of the procedures of rapid detection protocol for the diagnosis of citrus greening disease

Fig. 5. This protocol consists of three major steps: (1) extraction of template DNA from citrus tissue; (2) PCR amplification; and (3) analysis of PCR products. The entire procedure can be completed within a $6 \mathrm{~h}$ time period: $2 \mathrm{~h}$ for DNA extraction; $3 \mathrm{~h}$ for PCR; and $1 \mathrm{~h}$ for analysis of PCR products by agarose gel electrophoresis. The PCR-based assay is able to overcome difficulties caused by the low concentration and uneven distribution of GFB in citrus hosts.

The PCR-based assay detected almost all Asian GFB strains collected from different countries including Taiwan, Japan, China, Vietnam, Philippines, Malaysia, Thailand, India and Saudi Arabia, and is therefore useful for diagnosis of citrus greening in Asia. However, the GFB from South Africa could not be detected. For many years, two different types of citrus greening diseases have been recognized: one is the Asian type (heat-tolerant type), in which the symptoms of citrus greening occur at temperature above $30^{\circ} \mathrm{C}$; and the other is the African type (heat-sensitive type), in which no symptoms appear above $30^{\circ} \mathrm{C}($ BovJ et al., 1974). GFB has been recently characterized and tentatively named Liberobacter (Planet et al., 1995). By comparison of the $16 \mathrm{~S} / 23 \mathrm{~S}$ rDNA sequences, Jagoueix et al. (1997) categorized GFB into two different species, Asian GFB and African GFB. Asian GFB was named as Liberobacter asiaticum, and African GFB as Liberobacter africanum. According to the present results, the 226-primer pair is specific only to Liberobacter asiaticum. 
The southern hybridization results revealed that PCR products amplified from GFB-infected tissue by the use of the 226-primer pair are highly homologous to GSF1. In addition to the major bands of $226 \mathrm{bp}$, several minor bands (about $400 \mathrm{bp}$ ) could be detected by Southern hybridization. These minor bands could not be visualized on agarose gel under UV light after staining with EtBr, but are specific to diseased samples as they were not produced by healthy samples. The character of the minor band is unknown, but will be identified by further sequence analysis.

\section{Literature}

Bové, J. M., E. C. Calavin, S. P. Capoor, R. E. Cortez, R. E. Schwarz (1974): Influence of temperature on symptoms of California stubborn, South Africa greening, India citrus decline and Philippine leaf mottling disease. In: Weathers, L. G. and M. Cohen (eds), Proc. 6th Conference Int. Org. Citrus Virol., Riverside, pp. 12-15. IOCV, Riverside.

Garnier, M., N. Danel, J. M. Bové (1984): Aetiology of citrus greening disease. Ann. Microbiol. (Inst. Pasteur) 135A, 169-179.

Hung, T. H., M. L. Wu, H. J. Su (1999): Detection of fastidious bacteria causing citrus greening disease by nonradioactive DNA probes. Ann. Phytopath. Soc. Japan 65, 93-100.

Jagoueix, S., J. M. Bové, M. Garnier (1997): Comparison of the 16S/23S ribosomal intergenic regions of 'Candidatus Liberobacter asiatium' and 'Candidatus Liberobacter africanum', the two species associated with citrus huanglongbing (greening) disease. Am. Soc. Microbiol. 47, 224-227.

Lee, I. M., R. E. Davis (1988): Detection and investigation of genetic relatedness among aster yellows and other mycoplasma-like organisms by using cloned DNA and RNA probes. Mol. Plant-Microbe Interact. 1, 303-310

Lee, I. M., R. E. Davis, N. D. DeWitt (1990): Nonradioactive screening method for isolation of disease-specific probe to diagnose plant diseases caused by mycoplasmalike organisms. Appl. Environ. Microbiol. 56, 1471-1475.

Lee, I. M., R. E. Davis, R. Hammond, B. Kirkpatrick (1988): Cloned riboprobe for detection of a mycoplasmalike organism (MLO) Biochem. Biophys. Res. Commun. 155, 443-448.

Murashige, T., W. P. Bitters, E. M. Naver, C. N. Roistacher, P. B Holiday (1972): A technique of shoot tip grafting and its utilization towards recovering virus-free citrus clones. Hort. Science 7, 118-119.

Planet, P., S. Jagoueix, J. M. Bové, M. Gariner (1995): Detection and characterization of the African citrus greening Liberobacter by amplification, cloning, and sequencing of the rplKAJL-rpoBC operon. Curr. Microbiol. 30, 137-141.

Sambrook, J., E. T. Fritsch, T. I. Maniatis (1989): Molecular Cloning: A Laboratory Manual, 2nd edn. Cold Spring Harbor Laboratory, Cold Spring Harbor, NY.

Su, H. J., S. C. Chang (1974): Electron microscopical study on the heat and tetracycline responses, and ultra-structure of the pathogen complex causing citrus likubin disease. In: Proc. 8th Int. Cong Electron Microscopy, Vol. 2, pp. 628-629. Int. Cong. Electron Microscopy, Canberra, Australia.

Su, H. J., J. Y. Chu (1984): Modified technique of citrus shoot-tip grafting and rapid propagation method to obtain citrus budwoods free of citrus viruses and likubin organism. Proc. Int. Soc. Citriculture. 2, 332-334

Su, H. J., T. H. Hung, M. C. Tsai (1991): Recent developments on detection of citrus greening disease. In: Proc. 6th Int. Asia Pacific Workshop on 'Integrated Citrus Health Management', Kuala Lumpur, Malaysia, pp. 24-30. Asia Pacific Workshop, Kuala Lumpur, Malaysia. 